\title{
A STUDY ON E-RETAILING BASED CONSUMER PERCEPTION OF ELECTRONIC GOODS
}

\author{
BALAJI. P*, M. SURESH, U. GOKUL VIGNESH \& D. MURUGANANTHI
}

Assistant Professor, Department of Agriculture and Rural Management,

Tamil Nadu Agricultural University, Coimbatore, Tamil Nadu, India

\begin{abstract}
E-Retailing or E-Tailing is nothing but the buying and selling of product or service by means of electronic through mobile or internet etc. E-Tailing may also include the sales of business to consumer and business to business. In this current era, consumer durables, and market penetration in electronic retailing has increased day to day life. This study aims to consumer perception-based service quality to measure the electronics goods and customer satisfaction level on electronics goods of e-service quality. The survey goes on with the well-structured questionnaire. This is mainly based on Likert scaling techniques and percentage analysis and factor analysis to find out the consumer perception and satisfaction. It is good to buy electronics goods online, expect apparels we can buy other products like footwear, food, reservations of tickets.
\end{abstract}

KEYWORDS: E-Retailing, Consumer Satisfaction, E-Tailing, Consumer Perception \& Online Retailing

Received: Mar 18, 2019; Accepted: Apr 08, 2019; Published: May 07, 2019; Paper Id.: IJEEFUSJUN20198

\section{INTRODUCTION}

E-retailing, mostly called as e-tailing. It is nothing that buying through the online and some other media. After the dramatic growth of Information technology, many e-commerce sites was started in India. E-tailing accounts for $10 \%$ growth in e-commerce market. Probably the e-Retailing market in India is needed to be save time and also they estimated that 2.5 billion online users, has played significant role in business markets. There are several things to be common between online retail stores and direct stores. The process of billing to the customers and also to maintain better relationship with suppliers. Some website who sells electronics items like tablets, mobile phones, television, computers, and other durables. Flipkart, Amazon, Infibeam, Snapdeal, Future bazaar, Naaptol. An e-tailing business must have an innovative ideas to get successful. Those essential components are Attractive for business-to-consumer (B2C) e-commerce portal. The customers are selecting their goods which they needed and put them in their shopping cart. Finally, as in a real store, at the time of checkout, the system calculates the price to be paid for the products selected, a payment method: Customers will make their payments using ecash, credit or debit cards.

\section{OBJECTIVES}

- To determine the consumer perception-based quality of electronics goods to measure E-Qual service dimensions in the study area

- To identify the customer satisfaction level of electronics goods through e-service quality in the study area 


\section{METHODOLOGY}

The study is empirical in nature as the study aims to find out the "A study on consumer perception of E-Retailing services for electronics goods -Coimbatore city" The study is carried out with a survey through a structured questionnaire. The study is limited only to Coimbatore district. The survey conducted in top 2 malls (Brooke'sfield's mall and fun mall) the total respondents103. The sample size considered for the study is 120. The respondents are selected from the Coimbatore city. To draw a conclusion, statistical tool like MS- Excel was used to apply for Percentage analysis. Through SPSS, factor analysis was used to find the perception level of the respondents and socioeconomic factors.

\section{FINDINGS AND DISCUSSIONS}

\section{Gender of Sample Respondents}

The Gender particulars of sample respondents was analysed and mentioned below table. It could be inferred from the table 1 that, Majority $(61.16 \%)$ of the sample respondents were male and the rest were female. Majorly the male respondents buying the electronic products.

\section{Age of the Sample Respondent}

The sample respondent's age was classified into four categories, the class interval were considered viz., 2530years, 31-35years, 36-40years, and 41-45 years, were categories in the Table 2. From this Table 2. It could be clearly understood that the majority of the consumers are young and middle age consumers between the age groups 25-35years.

\section{Occupation of the Respondents}

The occupation of the sample respondents was classified into six categories viz., Government employee, Entrepreneur, Agriculture, Professional, Self-employed, Private employee which was furnished in the table. It could be inferred from the table 3 the majority (36.89\%) of the sample respondents were professional employee followed by the government employee (23.30percent) and the rest were agriculture, self-employee, private employee.

\section{Educational Status of Sample Respondents}

The educational status of the sample respondents was classified into three major categories viz., UG, PG, and Professional as given in the Table 4. It could be concluded from the Table 4. That $(53.39 \%)$ of the sample respondents were post graduate followed by under graduate $(27.18 \%)$ and the rest were professional degree holders, thus it could be inferred that none of the sample respondents were uneducated.

\section{Income of the Sample Respondents}

The income level of the sample respondents was classified into three categories viz., <20000, 20000-45000, 45000-60000 are given in the Table 5. It could be concluded from the Table 5 that (49.51\%) of sample respondents were 20000-45000 income level followed by 45000-60000 income level and the rest were <20000 income level. This shows that majority of the people in the Coimbatore city is under 20000-45000 purchasing the electronic goods.

\section{Favourite of Service Provider of the Sample Respondents}

Favourite service provider of the sample respondents was classified in the Table 6 , so to find the most service provider of the sample respondents, categories viz., amazon, flip kart, and snap deal. From the above Table 6 . It could be inferred that service provider Amazon (51.45\%) followed by the flip kart (38.83\%) and the rest were snap deal. 


\section{Order Preferences of the Sample Respondents}

Order preference of the sample respondents were classified into 4 categories viz. mobile, laptop, pen drive, lap guard. Are given in the Table 7. It could be inferred from the Table 7, majority of the sample respondents preferred mobile (37.86\%) followed by the lap top (33.98) percent and the rest were pen drive and lap guard.

\section{Buying in Online of the Sample Respondents}

The products that are bought mostly on the online shopping are classified into five categories viz., Electronic goods, Railway tickets booking, Food, Footwear and, Apparels are given in the Table 8. It could be inferred from the Table 8 that the majority of the products bought from the sample respondents (40.80) percent electronic goods, followed by the $(19.59 \%)$ apparels and the rest were railway tickets, food and footwear.

\section{Payment Mode of the Sample Respondents}

The payment mode of the sample respondents for buying online shopping were classified into four categories viz., Credit card, Debit card, Net banking, Cash on delivery as given in the Table 9. It could be inferred from the Table 9, that the majority of the sample respondents are using (39.80\%) Debit card, followed by the (29.12\%) Net banking, and the rest were using credit card and cash on delivery for their payment.

\section{Service Dimension for Satisfaction of the Electronic Goods Online}

The service dimension for electronics goods online are classified into eight categories they are, Evaluation of product, Support of product search, on time delivery, Website aesthetics, delivery arrangements, order tracking, transparency of billing, Customer support as given in the table 10. From the above table it could be inferred Table 10, that the service dimensions for satisfaction of the electronic goods online are order tracking place rank 1, followed by the web aesthetics rank 2 , transparency of billing rank 3 , on time delivery rank 4 , delivery arrangements rank 5 , customer support rank 6, Support of product search rank 7 and evaluation of product rank 8

\section{Overall Satisfaction of the Sample Respondents}

Overall satisfaction of the sample respondents was classified into three categories viz. Highly satisfied, Satisfied, Neutral as given in the Table 11. From the above table it could be inferred that the majority of the sample respondents were (57.28\%) satisfied with the buying of electronic goods and the rest were highly satisfied and also under neutral.

\section{KMO and Bartlett's Test for Dimension in Consumer Perception}

From the KMO and Bartlett's test says that it is mostly significant for perception of the dimension of the variables from Table 12.

\section{Multiple Regression for Dimensional and Satisfaction Index}

From the Table 13 the customer care is not significant so, for the satisfaction index expect the customer care al other variable are significant variable. The $\mathrm{p}$ value is significant, so the independent variables (dimensions) have influence on dependent variables (satisfaction index).

\section{Rotated Component Matrix}

From the above Table 14, it is concluded that the variables are taken into study were explained by 9 dimensions as 
shown above.

\section{CONCLUSIONS}

It is concluded that E-Tailing increases day to day all over the world. This study is mostly done in Coimbatore district (Tamil Nadu). The research is mainly concentrates on e-Retailing purchases of electronics goods. This study mainly aimed to develop a new model for business development. They were used to measure the consumer perception and also to find the customer satisfaction level. For measuring the consumer satisfaction level an index is proposed in this study. The index is known as (average perception scores given for each customer divided by average expectation scores given for each customer) and by getting proportional value, it has assumed to develop a satisfaction index. This study also discovers the e-service dimensions of their research problems. The perception wise dimensions that identified as namely, accessibility, Responsiveness, design tangibility customer care, perceived value, privacy, and security, assured service delivery, System reliability.

\section{REFERENCES}

1. Allard C.R van Riel. Veronica Liljander, Petra Jurriens (2001) Exploring consumer evaluations of e- service: a portal site', International journal of service industry management, vol.12, no.4, pp.359-377

2. Biswajit Roy(2017).study on consumer perception of E-Tailing services for electronic goods in Kolkata, International journal of management, IT and Engineering vol.4.no. 2.pg1-13.

3. Bajaj, S., \& Saini, H. K. Opinions of Consumers and Retailers for Commercialization of Smocked Utility Articles.

4. Carman, J.M. (1990), “Consumer perceptions of service quality: an assessment of the SERVQUAL dimensions”, Journal of Retailing,

5. Jyoti Arora, (2013, 'Prospect of E-Retailing In India', IOSR journal of computer engineering, vol.10, no.3, pp.11-15

6. Noor habibah arshad, norjansalika janom, isnainy mohd idris, consumer perceptions of internet retail service quality

7. Prof Boom Ahuja (2018) customer perception towards online buying of electronic products from Flip kart and Amazon.

\section{APPENDIX}

\section{TABLES}

Table 1: Gender Particulars of Sample Respondents

\begin{tabular}{|c|c|c|}
\hline S. No & Gender & No. of the Respondents(Percentage) \\
\hline 1 & Male & $63(61.16)$ \\
\hline 2 & Female & $40(38.83)$ \\
\hline & Total & $\mathbf{1 0 3 ( 1 0 0 . 0 0 )}$ \\
\hline
\end{tabular}

(Figures in parenthesis indicates to percentage total)

Table 2: Age Particulars of Sample Respondents

\begin{tabular}{|c|c|c|}
\hline S. No & Age & No. of Respondents (Percentage) \\
\hline 1 & $25-30$ Years & $37(35.92)$ \\
\hline 2 & $31-35$ Years & $35(33.98)$ \\
\hline 3 & $36-40$ Years & $22(21.35)$ \\
\hline 4 & $41-45$ years & $9(8.73)$ \\
\hline & Total & $\mathbf{1 0 3}(\mathbf{1 0 0})$ \\
\hline
\end{tabular}

(Figures in parenthesis indicates to percentage to total) 
Table 3: Occupation of Respondents

\begin{tabular}{|c|l|c|}
\hline S. no & Occupation & Number of the Respondents (Percentage) \\
\hline 1 & Government employee & $24(23.30)$ \\
\hline 2 & Entrepreneur & $1(0.97)$ \\
\hline 3 & Agriculture & $4(3.88)$ \\
\hline 4 & Professional & $38(36.89)$ \\
\hline 5 & Self-employee & $20(19.41)$ \\
\hline 6 & Private employee & $16(15.54)$ \\
\hline & Total & $\mathbf{1 0 3}(\mathbf{1 0 0})$ \\
\hline
\end{tabular}

(Figures in parenthesis indicates to percentage to total)

Table 4: Educational Status of Sample Respondents

\begin{tabular}{|c|l|c|}
\hline S. No & Educational status & Number of the Respondents (Percentage) \\
\hline 1 & UG & $28(27.18)$ \\
\hline 2 & PG & $55(53.39)$ \\
\hline 3 & Professional degree & $21(20.38)$ \\
\hline & Total & $\mathbf{1 0 3}(\mathbf{1 0 0})$ \\
\hline
\end{tabular}

(Figures in parenthesis indicates to percentage to total)

Table 5: Income of the Sample Respondents

\begin{tabular}{|c|c|c|}
\hline S. No & Income & Number of Respondents (Percentage) \\
\hline 1 & $<20000$ & $18(17.47)$ \\
\hline 2 & $20000-45000$ & $51(49.51)$ \\
\hline 3 & $45000-60000$ & $34(33.00)$ \\
\hline & Total & $\mathbf{1 0 3}(\mathbf{1 0 0})$ \\
\hline
\end{tabular}

(Figures in parenthesis indicates to percentage to total)

Table 6: Favorite of Service Provider of the Sample Respondents

\begin{tabular}{|c|l|c|}
\hline S. No & Service Provider & Number of Respondents (Percentage) \\
\hline 1 & Amazon & $53(51.45)$ \\
\hline 2 & Flip kart & $40(38.83)$ \\
\hline 3 & Snap deal & $10(9.70)$ \\
\hline & Total & $\mathbf{1 0 3}(\mathbf{1 0 0})$ \\
\hline
\end{tabular}

(Figures in parenthesis indicates to percentage to total)

Table 7: Order Preferences of the Sample Respondents

\begin{tabular}{|c|l|c|}
\hline S. No & Order Preference & Number of Respondents (Percentage) \\
\hline 1 & Mobile & $39(37.86)$ \\
\hline 2 & Laptop & $35(33.98)$ \\
\hline 3 & Pen-drive & $14(13.59)$ \\
\hline 4 & Lap guard & $15(14.56)$ \\
\hline & Total & $\mathbf{1 0 3}(\mathbf{1 0 0})$ \\
\hline
\end{tabular}

(Figures in parenthesis indicates to percentage to total)

Table 8: Buying in Online of the Sample Respondents

\begin{tabular}{|c|l|c|}
\hline S. No & Buying in Online & Number of Respondents (Percentage) \\
\hline 1 & Electronics goods & $42(40.80)$ \\
\hline 2 & Railway tickets booking & $13(12.62)$ \\
\hline 3 & Food & $16(15.56)$ \\
\hline 4 & Footwear & $12(11.65)$ \\
\hline 5 & Apparels & $20(19.59)$ \\
\hline & \multicolumn{1}{|c|}{ Total } & $\mathbf{1 0 3}(\mathbf{1 0 0})$ \\
\hline
\end{tabular}

(Figures in parenthesis indicates to percentage to total) 
Table 9: Payment Mode of the Sample Respondents

\begin{tabular}{|c|l|c|}
\hline S. No & Payment Mode & Number of Respondents (Percentage) \\
\hline 1 & Debit card & $41(39.80)$ \\
\hline 2 & Credit card & $10(9.70)$ \\
\hline 3 & Net banking & $30(29.12)$ \\
\hline 4 & Cash on delivery & $22(21.35)$ \\
\hline & Total & $\mathbf{1 0 3 ( 1 0 0 )}$ \\
\hline
\end{tabular}

(Figures in parenthesis indicates to percentage to total)

Table 10: Service Dimension for Satisfaction of the Electronics Goods Online

\begin{tabular}{|c|l|c|c|c|}
\hline S. No & \multicolumn{1}{|c|}{ Particulars } & Mean & Standard Deviation & Rank \\
\hline 1 & Order tracking & 3.98 & 2.94 & 1 \\
\hline 2 & Website aesthetics & 3.89 & 2.03 & 2 \\
\hline 3 & Transparency of billing & 3.30 & 1.14 & 3 \\
\hline 4 & On time delivery & 3.65 & 1.05 & 4 \\
\hline 5 & Delivery arrangements & 3.73 & 0.94 & 5 \\
\hline 6 & Customer support & 4.07 & 0.83 & 6 \\
\hline 7 & Support of product search & 4.03 & 0.82 & 7 \\
\hline 8 & Evaluation of the product & 3.82 & 0.82 & 8 \\
\hline
\end{tabular}

Table 11: Overall Satisfaction of the Sample Respondents

\begin{tabular}{|c|l|c|}
\hline S.No & Satisfaction Level & No of the Respondents (Percentage) \\
\hline 1 & Highly satisfied & $29(28.15)$ \\
\hline 2 & Satisfied & $59(57.28)$ \\
\hline 3 & Neutral & $15(14.56)$ \\
\hline & Total & $\mathbf{1 0 3}(\mathbf{1 0 0})$ \\
\hline
\end{tabular}

(Figures in parenthesis indicates to percentage to total)

Table 12: KMO and Bartlett's Test

\begin{tabular}{|lc|c|}
\hline Kaiser -Meyer-Olkin Measure of Sample Adequacy & .589 \\
Bartlett's Test of & Approx. Chi-Square & 725.501 \\
Sphericity df & 666 \\
& Sig, & .001 \\
\hline
\end{tabular}

Table 13: Multiple Regression for Dimensional and Satisfaction Index

\begin{tabular}{|c|c|c|c|c|c|}
\hline Model & Sum of Square & df & Mean Square & F & Sig. \\
\hline Residual & .617 & 93 & .007 & & \\
\hline Regression & 4.390 & 9 & .488 & 73.519 & .000 \\
\hline Total & $\mathbf{5 . 0 0 7}$ & $\mathbf{1 0 2}$ & & & \\
\hline
\end{tabular}

a. Predictors: (constant), assured service delivery, fulfilment, system reliability, design tangibility, accessibility, customer care, responsiveness, Perceived value, privacy and security.

b. Dependent variable: SI

Table 14: Coefficient

\begin{tabular}{|l|c|c|c|c|c|}
\hline \multirow{2}{*}{ Model } & \multicolumn{2}{|c|}{$\begin{array}{c}\text { Unstandardized } \\
\text { Coefficients Model }\end{array}$} & $\begin{array}{c}\text { Standardized } \\
\text { Coefficients }\end{array}$ & \multirow{2}{*}{ T } & \multirow{2}{*}{ Sig. } \\
\cline { 2 - 4 } & $\mathbf{B}$ & Std. Error & Beta & & \\
\hline \multicolumn{1}{|c|}{ (constant) } & 4.052 & .088 & & 504.871 & .000 \\
\hline Responsiveness & .061 & .088 & .277 & 7.609 & .000 \\
\hline Customer care & 0.010 & .088 & .043 & 1.180 & 0.24 \\
\hline Design tangibility & .109 & .088 & .490 & 13.458 & .000 \\
\hline System reliability & .088 & .088 & .397 & 10.908 & .000 \\
\hline Privacy and security & .042 & .088 & .189 & 5.200 & .000 \\
\hline Fulfilment & .080 & .088 & .361 & 9.919 & .000 \\
\hline
\end{tabular}




\begin{tabular}{|l|c|c|c|c|c|}
\hline \multicolumn{7}{|c|}{ Table 14: Contd., } \\
\hline Perceived value & .103 & .088 & .465 & 12.783 & .000 \\
\hline $\begin{array}{l}\text { Assured service } \\
\text { delivery }\end{array}$ & .024 & .088 & .107 & 2.943 & .004 \\
\hline Accessibility & .018 & .088 & .080 & 2.187 & .031 \\
\hline
\end{tabular}

A. Dependent variable: SI

Table 15: Rotated Component Matrix

\begin{tabular}{|c|c|c|c|c|c|c|c|c|c|}
\hline \multirow{2}{*}{ Particulars } & \multicolumn{9}{|c|}{ Component } \\
\hline & 1 & 2 & 3 & 4 & 5 & 6 & 7 & 8 & 9 \\
\hline They handles product returns. & .664 & & & & & & & & \\
\hline They offers a guarantee. & .627 & & & & & & & & \\
\hline $\begin{array}{l}\text { They provides with more options for } \\
\text { returning items. }\end{array}$ & .592 & & & & & & & & \\
\hline It quickly delivers the order. & & .660 & & & & & & & \\
\hline It is truthful to its offerings. & & .616 & & & & & & & \\
\hline The convenience of using the website. & & & .620 & & & & & & \\
\hline It delivers orders when promised. & & & .593 & & & & & & \\
\hline They launches and runs. & & & & .759 & & & & & \\
\hline It is well organized. & & & & .567 & & & & & \\
\hline $\begin{array}{l}\text { It makes promises about delivery of } \\
\text { products. }\end{array}$ & & & & & .675 & & & & \\
\hline Always available for business. & & & & & .610 & & & & \\
\hline $\begin{array}{l}\text { They will compensates use when what } \\
\text { we ordered doesn't arrive on time. }\end{array}$ & & & & & & .683 & & & \\
\hline $\begin{array}{l}\text { The prices of the products and services } \\
\text { available at this site (how economical } \\
\text { the site is). }\end{array}$ & & & & & & .569 & & & \\
\hline $\begin{array}{l}\text { The site makes the items available for } \\
\text { delivery within a suitable time. }\end{array}$ & & & & & & & 616 & & \\
\hline It does not crash. & & & & & & & & .741 & \\
\hline $\begin{array}{l}\text { It will enables me to get on to it } \\
\text { quickly. }\end{array}$ & & & & & & & & .603 & \\
\hline $\begin{array}{l}\text { They tells us what to do if our } \\
\text { transaction is not processed. }\end{array}$ & & & & & & & & & .669 \\
\hline $\begin{array}{l}\text { It has stock the items for company } \\
\text { claims to have. }\end{array}$ & & & & & & & & & .582 \\
\hline
\end{tabular}


